\title{
Challenges of higher education institutions against COVID-19: The case of Turkey
}

\author{
Abdulhamit Karademir1, Fatih Yaman² and Özkan Saatçioğlu ${ }^{3}$ \\ ${ }^{1}$ Muş Alparslan University, Faculty of Education, Turkey (ORCID: 0000-0003-3062-8547) \\ ${ }_{2}^{2} \mathrm{Muş}$ Alparslan University, Faculty of Education, Turkey (ORCID: 0000-0002-7425-1369) \\ ${ }^{3}$ Muş Alparslan University, Faculty of Education, Turkey (ORCID: 0000-0001-8131-9619)
}

\begin{abstract}
The global COVID-19 outbreak has caused an anxious situation in every part of society and forced many countries to implement distance education programs without even knowing the fundamental components involved in the processes and the consequences of their decisions. Likewise, in Turkey, it is still uncertain as to what will be taught, what instructional technologies will be employed, how infrastructural inequalities will be addressed, and how assessment and evaluation activities will be conducted. In this context, the purpose of this study was (a) to examine the experiences and opinions of academics, Distance Education Center managers, students, and parents and (b) offer solutions to emerging issues. In doing so, a qualitative research approach was employed, and the study was designed as a phenomenology. The data were collected from 175 individuals from 20 universities through Google Forms. The second cycle coding methods were employed in the analysis. The results indicated that COVID-19 had mostly psychological effects on individuals, and it affected every level of education at varying degrees. The pandemic reminded us how hopelessly we are dependent on traditional means of instruction by rendering us unable to use them. Since the beginning of the outbreak, many higher education institutions have been trying to implement distance education; however, the quality of instruction is rather questionable. This situation threatens the quality of learning outcomes and if not approached with due diligence, results could be catastrophic. Also, this mandatory transition to distance education has made the difference between the experienced and inexperienced academics more apparent. In light of the results, recommendations were provided for national and international policymakers. As long as the recommendations were implemented, all higher education stakeholders could attain the required knowledge and skills, and, in return, the adverse effects of the COVID-19 pandemic could be alleviated.
\end{abstract}

Keywords: Global outbreak; COVID-19; Higher education institutions; Academics; Students and families

Article History: Submitted 1 August 2020; Revised 25 September 2020; Published online 29 September 2020

\section{Introduction}

The COVID-19 outbreak originated in the Wuhan region of the People's Republic of China, posed an unprecedented global threat in the 21st century (Geldsetzer, 2020; Mahase, 2020; Wang, Horby et al., 2020). After World Health Organization (WHO) declared COVID-19 as a gruesome pandemic (Mahase, 2020; McAleer, 2020), many countries implemented isolation/quarantine measures and postponed schools at all levels to prevent the virus from spreading out (Anderson, Heesterbeek, Klinkenberg, \& Hollingsworth, 2020; Bayham \& Fenichel 2020; Brooks et al., 2020;

Address of Corresponding Author

Abdulhamit Karademir, PhD, Department of Pre-school Education, Faculty of Education, Muş Alparslan University, 49100, Muş, Turkey.

$\triangle$ a.karademir@alparslan.edu.tr

How to cite: Karademir, A., Yaman, F., \& Saatçioğlu, Ö. (2020). Challenges of higher education institutions against COVID-19: The case of Turkey. Journal of Pedagogical Research, 4(4), 453-474. 
Domenico, Pullano, Coletti, Hens, \& Colizza, 2020; Martel 2020; Wang, Zhang et al., 2020). Bayham and Fenichel (2020) and Anderson et al., 2020 stated that isolating cities and temporarily closing schools are of importance in lowering the number of infected individuals and preventing the spread of the disease. Therefore, the WHO suggested taking measures, and all educational institutions in the nation seized instruction to allow for social distancing (Bakker \& Wagner, 2020; Yue et al., 2020). In Turkey, the Ministry of National Education (MoNE) implemented an emergency plan to continue teaching and learning processes (Bayham \& Fenichel, 2020; Wang, Zhang et al., 2020), which included providing instructional content covering primary, secondary, and high school curricula through satellite TV broadcast and the Internet. Most higher education institutions over the globe switched to distance education (Rundle et al., 2020). Similarly, the Higher Education Council (HEC) of Turkey decided to conclude the 2019-2020 Spring semester through distance education.

\subsection{Distance Education}

Distance education is often associated with the internet; however, instructional activities have been conducted at a distance through various means even before the invention of the internet (Moore \& Kearsley, 2012). Distance education is instructional activities that bring all stakeholders of education together thorough communication technologies even though learners, teachers, teaching materials, and content are in physically different locations (Keegan, 1990). Distance education frees learners from the constraints of time and space, and it allows stakeholders to establish content delivery and learner-teacher interactions via various technologies (Kidd \& Song, 2007). Moore and Kearsley (2012) categorized distance education in five periods (Figure 1).

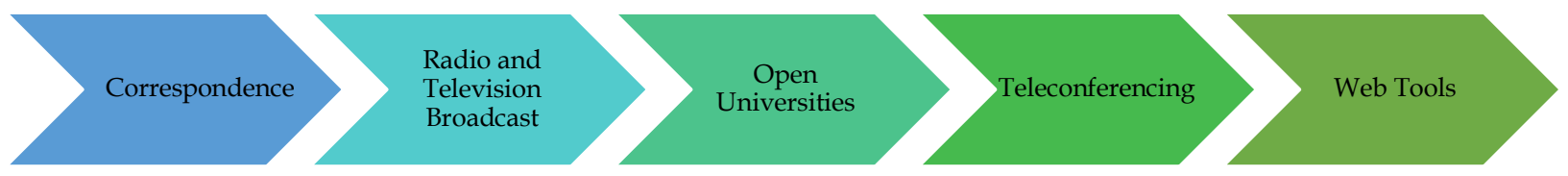

Figure 1. Distance education periods (adapted from Moore \& Kearsley, 2012)

As seen in Figure 1, the developments in distance education occurred in parallel to the technological advancements. These periods were initiated in Sweden in 1833 (Holmberg, 2008) and subsequently radio was used in education in the USA in 1921 (Moore \& Kearsley, 2012); educational broadcasts on television started in the USA in 1934 (Unwin \& McAleese, 1988); the British Open University started the period of open universities in 1967 (Moore \& Kearsley, 2012); until the 1990s, voice conversation provided over phone lines has turned into a video-supported structure with the developments in computer technologies, and it is seen that distance education applications have been adopted through teleconferences (Moore \& Kearsley, 2012) and web applications are used in distance education with the developments in Internet technologies. Similarly, Taylor (2001) divided distance education models into five generations presented in Figure 2.

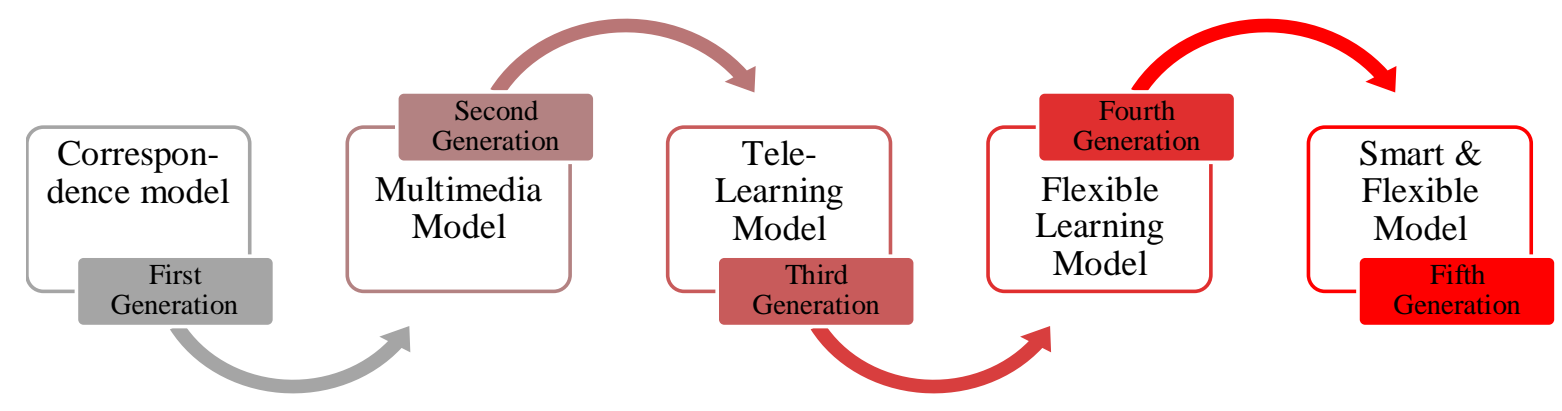

Figure 2. Distance education models (Taylor, 2001, p. 3) 
The classification in Figure 2 was built upon the technological advancements that Moore and Kearsley (2012) identified and organized in periods. The first generation embodied only textual mediums. The second generation extended it with audio, video, and interactive videos. The third generation added audio-conference, videoconference, voice and graphical communication, and radio/tv broadcasting. The fourth generation included interactive multimedia, internet-based content, computer-mediated communication. And the fifth generation covers interactive multimedia tools, internet-mediated content delivery, and e-campus portals to access institutional resources and functions. Caladine (2008) maintained that Taylor's model could be extended with a sixth generation named either Web 2.0 or E-Learning 2.0. According to Moore and Kearsley (2012) distance education;

- Provides access to instructional activities

- Updates individuals' skills for the workforce

- Is cost-effective

- Supports quality instruction

- Improves the capacity of education

- Balances inequalities among learners

- Reaches out to learners with special goals

- Could be implemented on an international scale.

Based on these features, Oranburg (2020) recommended the five steps of implementing distance education.

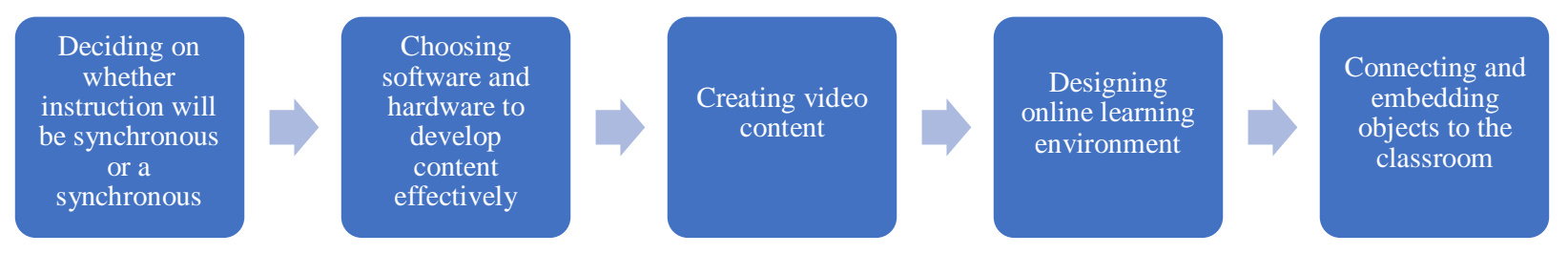

Figure 3. Distance education process (Oranburg, 2020, pp. 28-29)

As Figure 3 indicates, the first step of the distance education process is deciding on whether content delivery will be synchronous or asynchronous. It should be noted that synchronous delivery is more suitable for relatively small groups. In the second step, practitioners should choose hardware and software tools based on course content. Then, in the third step, video content should be created. In asynchronous delivery, the duration of videos should be around 5 to 10 minutes. For synchronous delivery, live meeting platforms such as Google Meet, Zoom, and WebEx could be used. Before designing the online environment in the fourth step, instructors should choose a content management platform and organize course content in weekly packages. In the fifth step, instructors should include tools for announcements, rapid troubleshooting, and providing feedback. Technology is indispensable in maintaining communications and interactions among instructors and learners. The advancements in technology, in return, strengthens the bond between distance learners and instructors. As Caladine (2008) proposed, in the sixth generation, the variety of tools that can be used in distance education has increased.

\subsection{Tools for Distance Education}

Interactive Web 2.0 technologies allow for numerous online activities such as content creation, sharing, and communication without needing users to have advanced technical skills. These technologies also benefit distance education activities by increasing effectiveness and user engagement. 
Table 1

Virtual classroom tools that can be used in distance learning

\begin{tabular}{|c|c|c|}
\hline Tools & Pros & Cons \\
\hline Google Classroom & $\begin{array}{l}\text { Free } \\
\text { Easy classroom join process } \\
\text { Ability to create multiple classrooms } \\
\text { Ability to add up to } 20 \text { instructors to } \\
\text { classroom } \\
\text { Deep integration with Google services } \\
\text { Ability to create custom assignments to } \\
\text { specific students } \\
\text { Platform agnostic }\end{array}$ & $\begin{array}{l}\text { Institiutional registration } \\
\text { required (Free) }\end{array}$ \\
\hline Edmodo & $\begin{array}{l}\text { Free } \\
\text { File and folder sharing } \\
\text { Integrated social sharing network } \\
\text { Ability to create small groups and assign } \\
\text { special activities to them } \\
\text { Platform agnostic }\end{array}$ & $\begin{array}{l}\text { Limited support for some } \\
\text { languages }\end{array}$ \\
\hline Easy Class & $\begin{array}{l}\text { Free } \\
\text { Ability to create Quizzes } \\
\text { Easy student monitoring through the } \\
\text { Gradebook feature } \\
\text { Easy material sharing through the Class } \\
\text { Library feature }\end{array}$ & $\begin{array}{l}\text { Only Web access } \\
\text { No support for mobile devices }\end{array}$ \\
\hline
\end{tabular}

As seen in Table 2, there are tools used in distance education. These tools have different features.

Table 2

Learning Management System (LMS) that can be used in distance learning

\begin{tabular}{lll}
\hline LMS & Pros & Cons \\
\hline BTutor & & \\
Claroline & Open sourced & \\
Dokeos & Free & No mobile application is \\
Drupal & & available \\
DotLRN & Extension support & \\
eFront & Support for various web platforms & \\
eStudy & Integrated measurement and assessment & \\
Moodle & tools & \\
OLAT & Results reporting & \\
Sakai & & Commercial \\
\hline Academic LMS & Presenting e-Learning content & \\
Blackboard Learn & Support for various web platforms & \\
Brightspace & Integrated assessment tools & \\
Schoology & & \\
\hline
\end{tabular}

Table 2 shows the advantages and disadvantages of LMS. Educators can choose the LMS suitable for them by considering these features. Table 3 includes applications that allow synchronous lessons that can be used in distance education. Although the tools presented in Table 1, Table 2, and Table 3 offer various integrated components for distance education, their effectiveness can be improved with other standalone tools. Some examples of such tools are provided in Table 4. 
Table 3

Synchronous (Live) classroom environments that can be used in distance learning

\begin{tabular}{lll}
\hline Live environments & Pros & Cons \\
\hline \multirow{2}{*}{ Google Meet } & Integration to Google Classroom & Free accounts are limited to 100 \\
& Meeting recording and sharing & participants and sessions are \\
& Multiplatform support & limit until Sept 30,2020) \\
\hline & Screen sharing & \\
Adobe Connect & Meeting recording and sharing & \\
& Screen sharing & Commercial \\
& Ability to create virtual classrooms & \\
& Various functions through components & \\
& Platform agnostic & \\
& Screen sharing & Commercial \\
Microsoft Teams & Multiplatform support & Institiutional registration \\
& Support for classroom meetings up to & required (Free) \\
& 10000 participants & \\
\hline
\end{tabular}

Table 4

Web 2.0 tools to enhance virtual classrooms

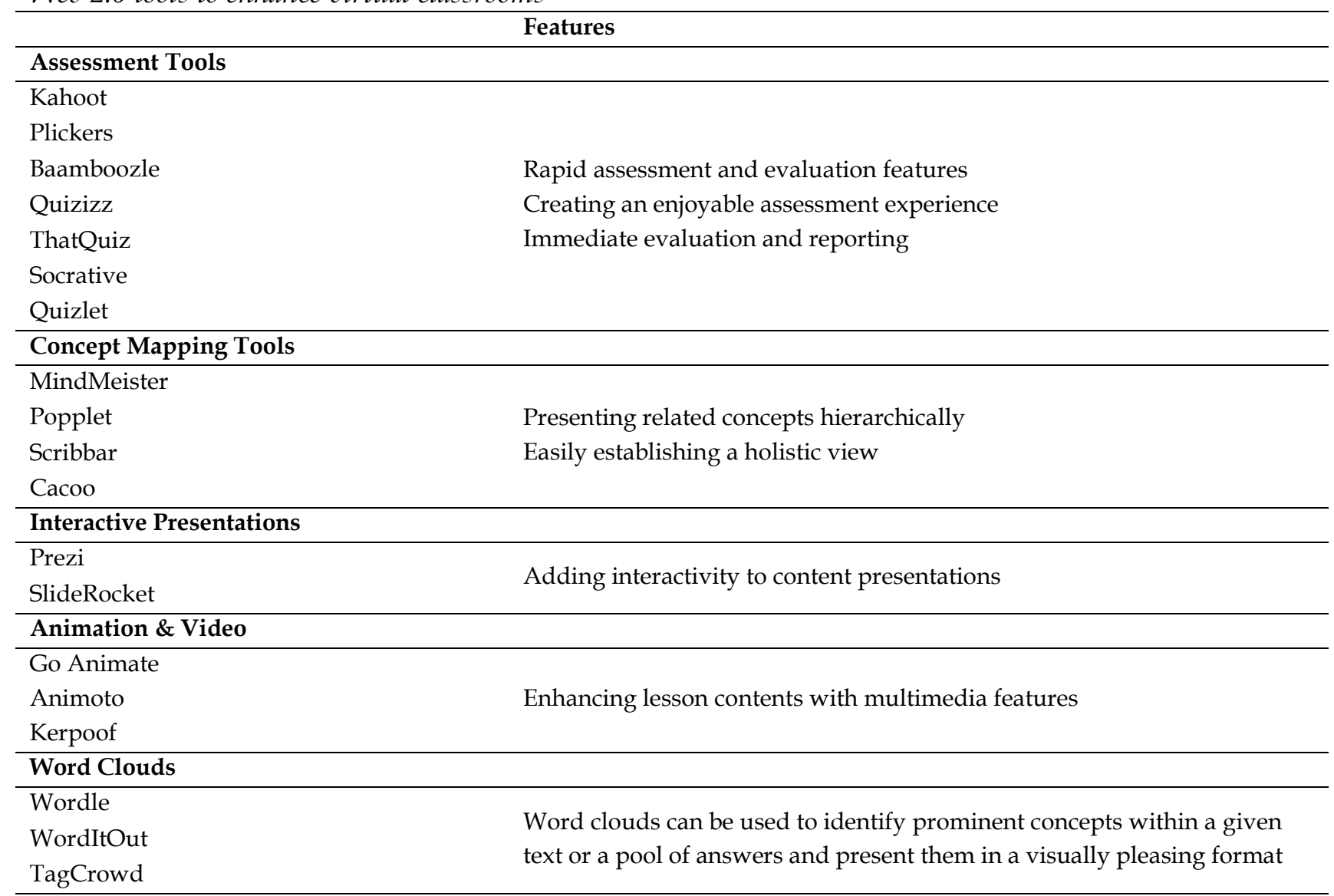

The effectiveness of distance education courses could be improved by incorporating the assessment, concept mapping, interactive presentation, video/animation, and word cloud tools presented in Table 4. With the Web 2.0 tools given in Table 4, measurement and evaluation can be done quickly. Both student-student and student-educator interaction can take place during assessment and evaluation. With concept map web 2.0 tools, students can be provided to see the concepts holistically. Students who have holistic information about concepts can easily understand 
the subject. Interactive presentation preparation tools for preparing presentations can also attract the attention of students. It is possible to prepare animations and videos about concepts that cannot be explained or shown in the classroom. There are different web 2.0 tools for this. It is possible to show prominent concepts about a topic with word clouds. In this context, distance education environment can become more effective with web 2.0 tools. These tools allow users to create visually appealing content that aids retention.

\subsection{Distance Education Process}

Transition to distance education has started at a national scale by implementing the "Suspending Classes Without Stopping Learning" policy (Zhang, Wang, Yang, \& Wang, 2020). The aim was to cease the spread of the virus without disrupting educational activities (Bao, 2020; Wang, Cheng et al., 2020). Distance education efforts have aimed to return most instructional activities to their regular basis and alleviate the raising concerns of students and parents of all levels of education (Wang, Zhang et al., 2020). In the process, many institutions and companies have provided free access to learning platforms, educational content, and software to exercise their social responsibility as much as possible (Bakker \& Wagner, 2020; Wang, Cheng et al., 2020). Like many countries (Manderson \& Levine, 2020), Turkey transferred all sorts of instructional activities to the digital medium. In the process, all universities in the country conducted activities to improve the quality of online content and support students and academics in the transition to distance education.

The Higher Education Council of Turkey oversaw the planning and implemented policy changes to guide and ease the transition. Besides, various groups within the society from academics to families tried to contribute to the process. Although the measures taken throughout the country have been necessary, the pandemic constantly creates new conditions (Luo, Liu, Yue, \& Rosen, 2020), which heightens students' concerns about their education. There is no consensus on the most effective ways to conduct distance education (Wang, Cheng et al., 2020; Zhang et al., 2020). Wang, Horby et al. (2020) stressed the importance of assuring quality in distance education activities started after the pandemic. In this context, UNESCO (2020)made the following recommendations for conducting teaching and learning activities during the pandemic:

- The most appropriate and common tools should be chosen

- Distance education programs should be inclusive

- Data privacy and security should be assured

- Solutions to psycho-social issues should come before teaching and learning

- Activities involved in distance education programs should be planned

- Technical support on the use of digital tools should be provided to teachers and parents

- Appropriate approaches should be combined, and the number of utilized applications and platforms should be limited

- Distance learning rules should be devised, and students' progress should be monitored

- The duration of distance education units should be determined based on the students' selfregulation skill levels.

- Communities should be formed, and connection should be provided

The pandemic has led to a process unfamiliar to many academics, students, and parents (Bakker \& Wagner, 2020; Erduran, 2020; Wang, Cheng et al., 2020). As students turned back to their family houses, they moved away from campus life and peers. In the meantime, they had to make changes in their lifestyles, accept limited freedom, and endure anxiety over the rapid spread of the disease (Brooks et al., 2020; Wang, Pan et al., 2020). In this fragile episode of life, families have become students' biggest supporters that share their concerns and worries (Zhao, Lyngs, \& Shadbolt, 2018). As students live together with family members who have lost their jobs or faced a decrease in income due to self-isolation, they experienced financial issues more profoundly. To top that off, multiple sources of issues, such as fear of getting infected, lack of outdoor activity, limited 
personal space, and unfavorable conditions for learning, threatens students' physical, mental, psychological health (Brooks et al., 2020; Wang, Cheng et al., 2020; Wang, Zhang et al., 2020). Wang, Cheng et al. (2020) reported that students have experienced high levels of stress, anxiety, and depression. Due to constant exposure to pandemic-related news, students' concerns for the future increase, and consequently, their motivation to study decreases and they have a hard time concentrating (Brooks et al., 2020).

Infrastructural differences among geographic regions and the often-limited technological facilities provided by universities may cause some inequalities among learners as well (Bakker \& Wagner, 2020; Bao, 2020; Zhang et al., 2020). Nonetheless, academics should provide quality instruction and fair assessment and evaluation activities to improve the effectiveness of distance education (Bakker \& Wagner, 2020; Erduran 2020; Wang, Zhang et al., 2020). As teaching and learning activities occur in the digital medium, academics and students need to participate using either a PC, laptop, tablet, or smartphone (Barr \& Miller, 2013). However, students of different socio-economical backgrounds may not have the same technological affordances (Zhang et al., 2020; Wang, Cheng et al., 2020). In this respect, insufficient technology ownership, connectivity issues due to network overload and infrastructure, lack of knowledge and skills about using digital tools, unfavorable household conditions, and failure to keep up with the coursework may have irreparable effects on students' education (Bakker \& Wagner, 2020; Zhang et al., 2020).

The pandemic threat may last for a long period and overcoming its adverse effects on higher education may take even longer (Erduran, 2020). All stakeholders of education from families to higher education institutions are jointly responsible for minimizing the adversities of the pandemic on students (Bakker \& Wagner, 2020; Wang, Cheng et al., 2020; Wang, Zhang et al., 2020). Academics need to improve their knowledge and skills about the effective use of digital technologies. In this context, higher education stakeholders should improve their readiness for emerging issues and prepare an intervention plan to deal with pandemic-related problems (Haushofer et al., 2020; Toquero, 2020). There exists a need for studies that examine the probable consequences of the pandemic in-depth (Zhang et al., 2020) and develop strategies to alleviate the adverse effects of the pandemic on parents, university students, and academics (Anderson et al., 2020). Hence, the purpose of this study was (a) to identify the current situation in Turkey by examining the experiences and opinions of academics, distance education center (DEC) managers, students, and parents, and (b) to recommend solutions to the emerging issues.

\section{Method}

In this qualitative study, a phenomenological research approach was employed. Phenomenology, in general, a research design that aims to reveal individuals' viewpoints, perceptions, and experiences by embodying their perceptions and lived experiences. Phenomenology studies focus on how individuals put together the phenomena they experience when making sense of the environment (Patton, 2014).

\subsection{Participants}

Participation in the study was voluntary and the snowball sampling method was employed. The sample included 112 university students (2-year, undergraduate, or graduate), 34 parents, 23 academics, and six DEC managers. The student participants were from 24 different programs at 20 universities. Parents were of 12 different occupations and academics represented eight different departments. Female percentages for the groups were $80 \%$ for students, $40 \%$ for parents, $30 \%$ for academics, and 30\% for DEC managers. The average ages of the students, parents, academics, and DEC managers were $21.68,48.43,37.38$, and 35 respectively.

\subsection{Data Collection}

Since face-to-face communications have been limited during the pandemic, the participants' opinions acquired through an online form created using Google Forms. To identify the pandemic's effects on higher education through multiple viewpoints, structured interview forms for each 
stakeholder group were developed using Google Forms. In doing so, first, the researchers identified the scope and context of the study and generated a question pool. Then, four experts from various academic backgrounds (e.g., measurement and evaluation, distance education, and language) reviewed the questions. Based on the feedback, the interview forms were revised, and the development process concluded. Therefore in order to obtain information about the participants, 10 questions about university, gender, age, etc. were formed, and 17 questions were created to get their opinions based on the participants' experiences in the distance education process. For example, "What would you like to say about the quality of the distance education being carried out?" or "What do you think about the quality of instructor-student interaction in the distance education process?" Such questions have been prepared for the participants to express their thoughts clearly. The Google Forms created was open for 15 days in April 2020 for participants to respond.

\subsection{Data Analysis Procedures}

In the data analysis, first, codes were generated based on the literature and the participants' opinions/expressions. Then, the codes organized into themes, subthemes, and categories to establish findings and aid interpretation (Krippendorff, 2013). The data were analyzed using the second cycle coding methods employed in qualitative research (Miles, Huberman, \& Saldana, 2014). In the first cycle, the researchers independently coded a piece of data and compared the generated codes. To verify the independently-generated themes and categories and eliminate subjective remarks, the researchers discussed the codes and created new themes and categories. In the second cycle, the researchers coded the remaining data employing the constant comparative method (Corbin \& Strauss, 2008). Then, the codes and findings were transferred to Nvivo to ease interpretation. Once data coding was complete, an external expert reviewed the codes and themes, and the researchers finalized the codes through consensus and presented them in table form.

\section{Findings}

Due to the pandemic, teaching and learning activities carried out through distance education technologies. The opinions of the stakeholders were analyzed in groups, namely leaders (DEC managers and academics) and followers (students and parents). The DEC managers' and academics' opinions about the distance education process are presented in Table 5.

Table 5

DEC managers' and academics' opinions towards distance education processes

\begin{tabular}{|c|c|c|c|}
\hline Theme & Subtheme & Category & Codes \\
\hline \multirow{13}{*}{ Infrastructure } & \multirow{4}{*}{ Tool Requirements } & \multirow{2}{*}{ Device } & Computer $\left(\mathrm{N}_{\mathrm{ACA}}=2, \mathrm{~N}_{\mathrm{MAN}}=1\right)$ \\
\hline & & & Smartphone $\left(\mathrm{N}_{\mathrm{ACA}}=1\right)$ \\
\hline & & \multirow{2}{*}{ Video Tools } & Camera $\left(\mathrm{N}_{\mathrm{MAN}}=1\right)$ \\
\hline & & & Tripod $\left(\mathrm{N}_{\mathrm{MAN}}=1\right)$ \\
\hline & \multirow{2}{*}{ Internet Access } & & No Access $\left(\mathrm{N}_{\mathrm{ACA}}=3\right)$ \\
\hline & & & Data-capped Internet Plan $\left(\mathrm{N}_{\mathrm{MAN}}=1\right)$ \\
\hline & \multirow{7}{*}{ System Requirement } & \multirow{3}{*}{ LMS } & Synchronous $\left(\mathrm{N}_{\mathrm{ACA}}=2, \mathrm{~N}_{\mathrm{MAN}}=3\right)$ \\
\hline & & & Asynchronous $\left(\mathrm{N}_{\mathrm{ACA}}=4, \mathrm{~N}_{\mathrm{MAN}}=1\right)$ \\
\hline & & & System load $\left(\mathrm{N}_{\mathrm{MAN}}=1\right)$ \\
\hline & & \multirow{4}{*}{$\begin{array}{l}\text { Synchronous } \\
\text { Lesson }\end{array}$} & Microsoft Teams $\left(\mathrm{N}_{\mathrm{MAN}}=3\right)$ \\
\hline & & & Google Meet $\left(\mathrm{N}_{\mathrm{MAN}}=1\right)$ \\
\hline & & & Zoom $\left(\mathrm{N}_{\mathrm{ACA}}=1\right)$ \\
\hline & & & Adobe Connect $\left(\mathrm{N}_{\mathrm{MAN}}=1\right)$ \\
\hline \multirow{5}{*}{ Psychology } & \multirow{5}{*}{ Uncertainty } & \multirow{2}{*}{ Anxiety-Stress } & Workload $\left(\mathrm{N}_{\mathrm{ACA}}=1\right)$ \\
\hline & & & $\operatorname{Exam}\left(\mathrm{N}_{\mathrm{ACA}}=2\right)$ \\
\hline & & \multirow{3}{*}{ Process } & Planlessness $\left(\mathrm{N}_{\mathrm{ACA}}=2\right)$ \\
\hline & & & Lack of Standards $\left(\mathrm{N}_{\mathrm{ACA}}=1, \mathrm{~N}_{\mathrm{MAN}}=1\right)$ \\
\hline & & & Application Variety $\left(\mathrm{N}_{\mathrm{MAN}}=1\right)$ \\
\hline
\end{tabular}


As seen in Table 5, the DEC managers' and academics' problems regarding the distance education processes revolve around infrastructural and psychological issues. The biggest barrier for both academics and students is the technological requirements. While some universities supported their personnel and provided devices, others made the academics responsible for meeting the technological requirements. Considering that some students do not have access to digital technologies such as computers and internet access, it becomes harder to assure equal opportunity and sustain the learning processes. Another aspect of infrastructure is the delivery medium employed in distance education. Depending on the preference for synchronous or asynchronous delivery, LMS offer different facilities. As service providers put forth usage limits (e.g., bandwidth, maximum simultaneous user count), universities depending on external services have experienced issues. Due to budget constraints, some universities without an established distance education infrastructure tried to leverage free services such as Google Meet to offer synchronous classroom meetings. Moreover, DEC managers and academics appear to experience psychological problems. The reason behind this situation is mostly uncertainty caused by the unplanned implementations, lack of standards, and varying applications from university to university. This uncertainty often leads to anxiety and stress. The most prominent antecedents of anxiety and stress are uncertainty about examination and grading, academics' lack of experience in distant course delivery, and increased workload.

DEC managers and academics hold great responsibilities for the effective conduct of distance education processes. Table 6 reflects the importance of the practitioners' individual differences and addressing their need for support.

Table 6

Academics in distance education processes

\begin{tabular}{|c|c|c|c|}
\hline Theme & Sub Theme & Category & Codes \\
\hline \multirow{6}{*}{$\begin{array}{l}\text { Individual } \\
\text { Differences }\end{array}$} & \multirow{4}{*}{ Digital Literacy } & \multirow{4}{*}{$\begin{array}{l}\text { Digital Native/Digital } \\
\text { Immigrant }\end{array}$} & Computer $\left(\mathrm{N}_{\mathrm{ACA}}=2\right)$ \\
\hline & & & Smartphone $\left(\mathrm{N}_{\mathrm{ACA}}=2\right)$ \\
\hline & & & Video Camera $\left(\mathrm{N}_{\mathrm{ACA}}=1\right)$ \\
\hline & & & Web 2.0 Tools $\left(\mathrm{N}_{\mathrm{AC}}=2\right)$ \\
\hline & \multirow{2}{*}{ Beliefs } & & Self-confidence $\left(\mathrm{N}_{\mathrm{ACA}}=1\right)$ \\
\hline & & & Insufficiency $\left(\mathrm{N}_{\mathrm{ACA}}=3\right)$ \\
\hline \multirow{2}{*}{ Support } & \multirow{2}{*}{ Technical Support } & & System Tutorials $\left(\mathrm{N}_{\mathrm{ACA}}=2\right)$ \\
\hline & & & Unit Responsibilities $\left(\mathrm{N}_{\mathrm{ACA}}=1\right)$ \\
\hline
\end{tabular}

ACA: Academics

The unforeseen situation caused by the pandemic forced many on-campus practitioners to adopt a course delivery medium that is significantly different than face-to-face instruction. The ones who experienced a smooth transition to distance education are often identified as digital natives or digital immigrants. Younger academics are usually more apt to utilize computers, smartphones, and web 2.0 technologies in teaching and adapt well to the distance education processes. Nonetheless, the academics differ in their beliefs regarding the soundness of the distance education endeavors. Some groups reported that they have experienced a problem-free and successful implementation, whereas others expressed feeling inadequate to conduct activities properly. For the academics who felt inadequate, universities provided online and offline tutorials about synchronous and asynchronous course delivery. In addition, they assigned support personnel to departments so that academics could receive help as needed. At this point, we could say that the support provided to the academics was merely technical and was not sufficient to ensure the quality of the instructional processes. Table 7 reflects the structure that emerged from the answers given to the questions regarding the quality of distance education. 
Table 7

Quality of distance education

\begin{tabular}{|c|c|c|c|}
\hline Theme & Sub Theme & Category & Codes \\
\hline \multirow{9}{*}{ Content } & \multirow{3}{*}{ Material } & \multirow{3}{*}{ One Type } & Class Notes $\left(\mathrm{N}_{\mathrm{ACA}}=2\right)$ \\
\hline & & & Presentation File $\left(\mathrm{N}_{\mathrm{ACA}}=3\right)$ \\
\hline & & & $\operatorname{Video}\left(\mathrm{N}_{\mathrm{ACA}}=1\right)$ \\
\hline & \multirow{6}{*}{ Content Presentation } & \multirow{6}{*}{ Method } & Direct Instruction $\left(\mathrm{N}_{\mathrm{ACA}}=3\right)$ \\
\hline & & & Expository Teaching $\left(\mathrm{N}_{\mathrm{ACA}}=2\right)$ \\
\hline & & & Discovery Learning $\left(\mathrm{N}_{\mathrm{ACA}}=1\right)$ \\
\hline & & & Discussion $\left(\mathrm{N}_{\mathrm{ACA}}=2\right)$ \\
\hline & & & Case Study $\left(\mathrm{N}_{\mathrm{ACA}}=1\right)$ \\
\hline & & & Question \& Answer $\left(\mathrm{N}_{\mathrm{ACA}}=1\right)$ \\
\hline \multirow{14}{*}{ Feasibility } & \multirow{2}{*}{ Academics (Instructor) } & & Skill $\left(\mathrm{N}_{\mathrm{ACA}}=3\right)$ \\
\hline & & & Experience $\left(\mathrm{N}_{\mathrm{ACA}}=2\right)$ \\
\hline & \multirow{7}{*}{ Opinion } & \multirow{2}{*}{ Positive } & Best Method $\left(\mathrm{N}_{\mathrm{ACA}}=4\right)$ \\
\hline & & & Complementary $\left(\mathrm{N}_{\mathrm{ACA}}=3\right)$ \\
\hline & & \multirow{5}{*}{ Negative } & Efficiency $\left(\mathrm{N}_{\mathrm{ACA}}=4\right)$ \\
\hline & & & Equal Opportunity $\left(\mathrm{N}_{\mathrm{ACA}}=5\right)$ \\
\hline & & & Restrictive $\left(\mathrm{N}_{\mathrm{ACA}}=2\right)$ \\
\hline & & & Short Term $\left(\mathrm{N}_{\mathrm{ACA}}=2\right)$ \\
\hline & & & Interaction $\left(\mathrm{N}_{\mathrm{ACA}}=1\right)$ \\
\hline & \multirow{5}{*}{ Stakeholder } & \multirow{2}{*}{$\begin{array}{l}\text { Socio-economical } \\
\text { States }\end{array}$} & Residency $\left(\mathrm{N}_{\mathrm{ACA}}=2\right)$ \\
\hline & & & Financial Disadvantage $\left(\mathrm{N}_{\mathrm{ACA}}=3\right)$ \\
\hline & & \multirow{3}{*}{ Psychological } & Eagerness $\left(\mathrm{N}_{\mathrm{ACA}}=2\right)$ \\
\hline & & & Exam Anxiety $\left(\mathrm{N}_{\mathrm{ACA}}=5\right)$ \\
\hline & & & Graduation $\left(\mathrm{N}_{\mathrm{ACA}}=2\right)$ \\
\hline
\end{tabular}

ACA: Academics

In distance education, content delivery is of importance, and providing materials in only one form is not acceptable. Content delivery should be enriched with various materials, and effective instructional methods should be selected and executed. Another rising concern is whether the materials and lessons comply with well-established instructional design principles. The practitioners stressed that academics should have sufficient knowledge and experience in distance education to undergo the process efficiently. Also, it appears that the participants voice their concerns about issues and the feasibility of distance education more frequently. Given conditions caused by the pandemic, the practitioners acknowledged that distance education is the most appropriate means to continue educational activities. The institutions' failure to provide equal opportunities was surfaced also within the stakeholder context. The socio-economical and psychological states of the stakeholders had detrimental effects on the feasibility of the process. The students' concerns about examination and graduation prevented the process from going properly.

Aside from DEC managers and academics, the pandemic-driven distance education process has affected the daily lives of students and parents. Table 8 presents the process' influences on students and parents in detail. 
Table 8

The pandemic's effect on daily life

\begin{tabular}{|c|c|c|c|}
\hline Theme & Sub Theme & Category & Codes \\
\hline \multirow{24}{*}{ Life } & \multirow{11}{*}{ Student } & \multirow{8}{*}{ Psychological effect } & Fear of getting sick $\left(\mathrm{N}_{\mathrm{PAR}}=18, \mathrm{~N}_{\mathrm{STU}}=89\right)$ \\
\hline & & & Stress/anxiety $\left(\mathrm{N}_{\mathrm{STU}}=102\right)$ \\
\hline & & & Boredom $\left(\mathrm{N}_{\mathrm{PAR}}=12, \mathrm{~N}_{\mathrm{STU}}=85\right)$ \\
\hline & & & Lack of motivation $\left(\mathrm{N}_{\mathrm{PAR}}=22, \mathrm{~N}_{\mathrm{STU}}=72\right)$ \\
\hline & & & Pessimism $\left(\mathrm{N}_{\mathrm{PAR}}=8, \mathrm{~N}_{\mathrm{STU}}=67\right)$ \\
\hline & & & Fatigue $\left(\mathrm{N}_{\mathrm{PAR}}=5, \mathrm{~N}_{\mathrm{STU}}=32\right)$ \\
\hline & & & Emotional challenges $\left(\mathrm{N}_{\mathrm{PAR}}=10, \mathrm{~N}_{\mathrm{STU}}=21\right)$ \\
\hline & & & Feeling lonely $\left(\mathrm{N}_{\mathrm{PAR}}=2, \mathrm{~N}_{\mathrm{STU}}=19\right)$ \\
\hline & & \multirow{3}{*}{ Behaviors } & Diminishing/lowering social life $\left(\mathrm{N}_{\mathrm{PAR}}=11, \mathrm{~N}_{\mathrm{STU}}=78\right)$ \\
\hline & & & Turning to different individual activities $\left(\mathrm{N}_{\mathrm{PAR}}=3, \mathrm{~N}_{\mathrm{STU}}=42\right)$ \\
\hline & & & Different emotional tendencies $\left(\mathrm{N}_{\mathrm{PAR}}=1, \mathrm{~N}_{\mathrm{STU}}=4\right)$ \\
\hline & \multirow{13}{*}{ Family } & \multirow{6}{*}{ Psychological effect } & Nervousness $\left(\mathrm{N}_{\mathrm{PAR}}=28, \mathrm{~N}_{\mathrm{STU}}=12\right)$ \\
\hline & & & Boredom $\left(\mathrm{N}_{\mathrm{PAR}}=6, \mathrm{~N}_{\mathrm{STU}}=26\right)$ \\
\hline & & & Fear $\left(\mathrm{N}_{\mathrm{PAR}}=24, \mathrm{~N}_{\mathrm{STU}}=4\right)$ \\
\hline & & & Sadness (N $\left.\mathrm{N}_{\mathrm{PAR}}=14, \mathrm{~N}_{\mathrm{STU}}=13\right)$ \\
\hline & & & Stress $\left(\mathrm{N}_{\mathrm{PAR}}=9, \mathrm{~N}_{\mathrm{STU}}=8\right)$ \\
\hline & & & Impatience / Burnout $\left(\mathrm{N}_{\mathrm{PAR}}=6, \mathrm{~N}_{\mathrm{STU}}=10\right)$ \\
\hline & & \multirow{4}{*}{ Behaviors } & Isolation $\left(\mathrm{N}_{\mathrm{PAR}}=12, \mathrm{~N}_{\mathrm{STU}}=24\right)$ \\
\hline & & & Chancing habits $\left(\mathrm{N}_{\mathrm{PAR}}=18, \mathrm{~N}_{\mathrm{STU}}=9\right)$ \\
\hline & & & Family quarrels $\left(\mathrm{N}_{\mathrm{PAR}}=6, \mathrm{~N}_{\mathrm{STU}}=11\right)$ \\
\hline & & & Acceptance (getting used to) $\left(\mathrm{N}_{\mathrm{PAR}}=10, \mathrm{~N}_{\mathrm{STU}}=2\right)$ \\
\hline & & \multirow{3}{*}{ Conditions } & Rural life $\left(\mathrm{N}_{\mathrm{PAR}}=26, \mathrm{~N}_{\mathrm{STU}}=27\right)$ \\
\hline & & & Unfavorable house conditions $\left(\mathrm{N}_{\mathrm{PAR}}=14, \mathrm{~N}_{\mathrm{STU}}=30\right)$ \\
\hline & & & Financial issues $\left(\mathrm{N}_{\mathrm{PAR}}=8, \mathrm{~N}_{\mathrm{STU}}=13\right)$ \\
\hline
\end{tabular}

PAR: Parents; STU: Students

From the students' perspectives, the psychological effects of the pandemic appear to include high levels of stress and anxiety as well as fear of getting infected. As the pandemic prevention measures required students to stay at home with family members, they expressed increasing boredom. While students were struggling to adapt to the mandatory changes, they also experienced a decrease in motivation to study. As their social life and sharing activities came closer to a stop, students experience emotional strain and psychological fatigue. Individuals also grow more pessimistic due to the relatively unchanging state of the pandemic. The students stated that they turned to different indoor activities to ease the psychological burden. Reading, doing basic exercises, watching movies, and spending time online were among the activities they perform. Some students reported that they had moved to rural areas with their families and avoided crowded environments to safeguard their health.

Due to the infection risk, almost every member of the family got scared and nervous. This unexpected situation forced family members to stay together for prolonged times while struggling with negative emotions, and that sometimes leads to increasing tension and intolerance. Individuals also experienced emotional wear because they felt sad about their relatives who have financial issues due to the disease and who are at risk of getting infected. Parents and other family members also had to change their daily habits and adapt to new work conditions. Despite the hardship experienced first, all seem to get used to the changes caused by the pandemic. In addition to daily life, the pandemic has also affected education and consequently the students (see Table 9). 
Table 9

The pandemic's effects on education

\begin{tabular}{|c|c|c|c|c|}
\hline Theme & Subtheme & Category & Subcategory & Codes \\
\hline \multirow{42}{*}{$\begin{array}{l}\text { Educational } \\
\text { Process }\end{array}$} & \multirow{42}{*}{$\begin{array}{l}\text { Distance } \\
\text { Education }\end{array}$} & \multirow{12}{*}{ Content } & \multirow{6}{*}{ Activities } & Surface $\left(\mathrm{N}_{\mathrm{STU}}=105\right)$ \\
\hline & & & & Theoretical $\left(\mathrm{N}_{\mathrm{STU}}=103\right)$ \\
\hline & & & & Asynchronous $\left(\mathrm{N}_{\mathrm{STU}}=97\right)$ \\
\hline & & & & Temporary (short term) $\left(\mathrm{N}_{\mathrm{STU}}=89\right)$ \\
\hline & & & & Concentration Problems $\left(\mathrm{N}_{\mathrm{STU}}=67\right)$ \\
\hline & & & & Synchronous $\left(\mathrm{N}_{\mathrm{STU}}=15\right)$ \\
\hline & & & \multirow{6}{*}{ Process } & Uncertainty $\left(\mathrm{N}_{\mathrm{STU}}=104\right)$ \\
\hline & & & & Inefficient $\left(\mathrm{N}_{\mathrm{STU}}=100\right)$ \\
\hline & & & & One-Sided / Individual learning $\left(\mathrm{N}_{\mathrm{STU}}=96\right)$ \\
\hline & & & & Unjust $\left(\mathrm{N}_{\mathrm{STU}}=93\right)$ \\
\hline & & & & Worrisome $\left(\mathrm{N}_{\mathrm{STU}}=88\right)$ \\
\hline & & & & Mistrust $\left(\mathrm{N}_{\mathrm{STU}}=17\right)$ \\
\hline & & \multirow{16}{*}{$\begin{array}{l}\text { Academics } \\
\text { (Instructor) }\end{array}$} & \multirow{3}{*}{ Experience } & Shortcomings $\left(\mathrm{N}_{\mathrm{STU}}=69, \mathrm{~N}_{\mathrm{ACA}} 9\right)$ \\
\hline & & & & $\begin{array}{l}\text { Inability to Perform as Desired }\left(\mathrm{N}_{\mathrm{STU}}=46,\right. \\
\left.\mathrm{N}_{\mathrm{ACA}}=15\right)\end{array}$ \\
\hline & & & & Hardship $\left(\mathrm{N}_{\mathrm{STU}}=47, \mathrm{~N}_{\mathrm{ACA}}=5\right)$ \\
\hline & & & \multirow{7}{*}{ Process } & $\begin{array}{l}\text { Increasing Responsibilities }\left(\mathrm{N}_{\mathrm{STU}}=61, \mathrm{~N}_{\mathrm{ACA}}=23,\right. \\
\left.\mathrm{N}_{\mathrm{MAN}}=2\right)\end{array}$ \\
\hline & & & & $\begin{array}{l}\text { Challenge to Preserve Quality }\left(\mathrm{N}_{\mathrm{STU}}=57,\right. \\
\left.\mathrm{N}_{\mathrm{ACA}}=9, \mathrm{~N}_{\mathrm{MAN}}=3\right)\end{array}$ \\
\hline & & & & Uncertainty $\left(\mathrm{N}_{\mathrm{STU}}=58, \mathrm{~N}_{\mathrm{ACA}}=6\right)$ \\
\hline & & & & Workload $\left(\mathrm{N}_{\mathrm{STU}}=37, \mathrm{~N}_{\mathrm{ACA}}=20\right)$ \\
\hline & & & & Getting Used to the System $\left(\mathrm{N}_{\mathrm{STU}}=32, \mathrm{~N}_{\mathrm{ACA}}=15\right)$ \\
\hline & & & & $\begin{array}{l}\text { Troubles- Limitations }\left(\mathrm{N}_{\mathrm{STU}}=15, \mathrm{~N}_{\mathrm{ACA}}=19\right. \\
\left.\mathrm{N}_{\mathrm{MAN}}=2\right)\end{array}$ \\
\hline & & & & Requirements $\left(\mathrm{N}_{\mathrm{STU}}=8, \mathrm{~N}_{\mathrm{ACA}}=20, \mathrm{~N}_{\mathrm{MAN}}=1\right)$ \\
\hline & & & \multirow{6}{*}{ Psychology } & Worry/ Uneasiness/ Anxiety $\left(\mathrm{N}_{\mathrm{STU}}=\mathrm{N}_{\mathrm{ACA}}=95\right)$ \\
\hline & & & & Similar Feelings $\left(\mathrm{N}_{\mathrm{STU}}=76, \mathrm{~N}_{\mathrm{ACA}}=12\right)$ \\
\hline & & & & Dissatisfaction $\left(\mathrm{N}_{\mathrm{STU}}=63, \mathrm{~N}_{\mathrm{ACA}}=8\right)$ \\
\hline & & & & Feeling Forced $\left(\mathrm{N}_{\mathrm{STU}}=28 \mathrm{~N}_{\mathrm{ACA}}=11\right)$ \\
\hline & & & & Bewilderment - Curiosity $\left(\mathrm{N}_{\mathrm{STU}}=12, \mathrm{~N}_{\mathrm{ACA}}=2\right)$ \\
\hline & & & & Academic relief $\left(\mathrm{N}_{\mathrm{STU}}=2, \mathrm{~N}_{\mathrm{ACA}}=5\right)$ \\
\hline & & \multirow{6}{*}{ Feasibility } & & Unpreparedness $\left(\mathrm{N}_{\mathrm{STU}}=98, \mathrm{~N}_{\mathrm{ACA}}=11\right)$ \\
\hline & & & & Deficiencies $\left(\mathrm{N}_{\mathrm{STU}}=88, \mathrm{~N}_{\mathrm{ACA}}=20\right)$ \\
\hline & & & & Inefficiency $\left(\mathrm{N}_{\mathrm{STU}}=99, \mathrm{~N}_{\mathrm{ACA}}=7\right)$ \\
\hline & & & & Uncertainties $\left(\mathrm{N}_{\mathrm{STU}}=87, \mathrm{~N}_{\mathrm{ACA}}=18\right)$ \\
\hline & & & & Infrastructural Problems $\left(\mathrm{N}_{\mathrm{STU}}=88, \mathrm{~N}_{\mathrm{ACA}}=6\right)$ \\
\hline & & & & Departmental Differences $\left(\mathrm{N}_{\mathrm{STU}}=71, \mathrm{~N}_{\mathrm{ACA}}=20\right)$ \\
\hline & & \multirow{8}{*}{ Accessibility } & \multirow{3}{*}{$\begin{array}{l}\text { Teacher- } \\
\text { Learner } \\
\text { Communication }\end{array}$} & Inefficient $\left(\mathrm{N}_{\mathrm{STU}}=85, \mathrm{~N}_{\mathrm{ACA}}=7\right)$ \\
\hline & & & & One-sided/ Asynchronous $\left(\mathrm{N}_{\mathrm{STU}}=84, \mathrm{~N}_{\mathrm{ACA}}=5\right)$ \\
\hline & & & & Lack of briefing $\left(\mathrm{N}_{\mathrm{STU}}=75, \mathrm{~N}_{\mathrm{ACA}}=2\right)$ \\
\hline & & & \multirow{5}{*}{$\begin{array}{l}\text { Access to the } \\
\text { system }\end{array}$} & Needs improvement $\left(\mathrm{N}_{\mathrm{STU}}=88, \mathrm{~N}_{\mathrm{ACA}}=9\right)$ \\
\hline & & & & Connection/ Access Issues $\left(\mathrm{N}_{\mathrm{STU}}=80\right)$ \\
\hline & & & & Aggrievement / Victimization $\left(\mathrm{N}_{\mathrm{STU}}=80\right)$ \\
\hline & & & & Technological Insufficiency $\left(\mathrm{N}_{\mathrm{STU}}=61\right)$ \\
\hline & & & & Costly $\left(\mathrm{N}_{\mathrm{STU}}=19\right)$ \\
\hline
\end{tabular}


Table 9 continued

\begin{tabular}{|c|c|c|c|c|}
\hline Theme & Subtheme & Category & Subcategory & Codes \\
\hline \multirow{26}{*}{$\begin{array}{l}\text { Educational } \\
\text { Process }\end{array}$} & \multirow{26}{*}{$\begin{array}{l}\text { Face to Face } \\
\text { Instruction }\end{array}$} & \multirow{9}{*}{$\begin{array}{l}\text { Students } \\
\text { (Learners) }\end{array}$} & \multirow{4}{*}{ Emotional effect } & High Motivation $\left(\mathrm{N}_{\mathrm{STU}}=92, \mathrm{~N}_{\mathrm{PAR}}=11\right)$ \\
\hline & & & & Interest - Eagerness $\left(\mathrm{N}_{\mathrm{STU}}=71, \mathrm{~N}_{\mathrm{PAR}}=15\right)$ \\
\hline & & & & Emotional Exchange $\left(\mathrm{N}_{\mathrm{STU}}=63\right)$ \\
\hline & & & & Curiosity $\left(\mathrm{N}_{\mathrm{STU}}=46\right)$ \\
\hline & & & \multirow{5}{*}{$\begin{array}{l}\text { Academical } \\
\text { effect }\end{array}$} & One-to-One Interaction $\left(\mathrm{N}_{\mathrm{STU}}=101\right)$ \\
\hline & & & & Active Participation $\left(\mathrm{N}_{\mathrm{STU}}=96\right)$ \\
\hline & & & & Retention $\left(\mathrm{N}_{\mathrm{STU}}=58, \mathrm{~N}_{\mathrm{PAR}}=21\right)$ \\
\hline & & & & Mastery Learning $\left(\mathrm{N}_{\mathrm{STU}}=31, \mathrm{~N}_{\mathrm{PAR}}=17\right)$ \\
\hline & & & & Readiness $\left(\mathrm{N}_{\mathrm{STU}}=27\right)$ \\
\hline & & \multirow{6}{*}{$\begin{array}{l}\text { Academics } \\
\text { (Instructors) }\end{array}$} & \multirow{2}{*}{ Emotional effect } & Self-confidence $\left(\mathrm{N}_{\mathrm{ACA}}=20, \mathrm{~N}_{\mathrm{MAN}}=3\right)$ \\
\hline & & & & Empathy $\left(\mathrm{N}_{\mathrm{ACA}}=18, \mathrm{~N}_{\mathrm{MAN}}=1\right)$ \\
\hline & & & \multirow{4}{*}{$\begin{array}{l}\text { Academical } \\
\text { effect }\end{array}$} & Effective Instruction $\left(\mathrm{N}_{\mathrm{ACA}}=74, \mathrm{~N}_{\mathrm{MAN}}=4\right)$ \\
\hline & & & & Intervention $\left(\mathrm{N}_{\mathrm{ACA}}=72, \mathrm{~N}_{\mathrm{MAN}}=1\right)$ \\
\hline & & & & Immediate Feedback $\left(\mathrm{N}_{\mathrm{ACA}}=58, \mathrm{~N}_{\mathrm{MAN}}=5\right)$ \\
\hline & & & & Repeating (Tekrar) $\left(\mathrm{N}_{\mathrm{ACA}}=45\right)$ \\
\hline & & \multirow{11}{*}{ Process } & \multirow{4}{*}{ Emotional effect } & Feeling confident $\left(\mathrm{N}_{\mathrm{STU}}=50, \mathrm{~N}_{\mathrm{ACA}}=16\right)$ \\
\hline & & & & Honesty $\left(\mathrm{N}_{\mathrm{STU}}=12, \mathrm{~N}_{\mathrm{ACA}}=26\right)$ \\
\hline & & & & Taking serious $\left(\mathrm{N}_{\mathrm{STU}}=10, \mathrm{~N}_{\mathrm{ACA}}=34\right)$ \\
\hline & & & & $\begin{array}{l}\text { Motivating classroom environment }\left(\mathrm{N}_{\mathrm{STU}}=3 \text {, }\right. \\
\left.\mathrm{N}_{\mathrm{ACA}}=14\right)\end{array}$ \\
\hline & & & \multirow{4}{*}{$\begin{array}{l}\text { (Teaching) } \\
\text { Methods }\end{array}$} & Active Learning $\left(\mathrm{N}_{\mathrm{STU}}=81, \mathrm{~N}_{\mathrm{ACA}}=18\right)$ \\
\hline & & & & Question \& Answer $\left(\mathrm{N}_{\mathrm{STU}}=66, \mathrm{~N}_{\mathrm{ACA}}=20\right)$ \\
\hline & & & & Discussion $\left(\mathrm{N}_{\mathrm{STU}}=68, \mathrm{~N}_{\mathrm{ACA}}=14\right)$ \\
\hline & & & & Learning by Doing $\left(\mathrm{N}_{\mathrm{STU}}=62, \mathrm{~N}_{\mathrm{ACA}}=12\right)$ \\
\hline & & & \multirow{3}{*}{$\begin{array}{l}\text { Academical } \\
\text { effect }\end{array}$} & Efficiency $\left(\mathrm{N}_{\mathrm{STU}}=86, \mathrm{~N}_{\mathrm{ACA}}=16, \mathrm{~N}_{\mathrm{MAN}}=1\right)$ \\
\hline & & & & Quality $\left(\mathrm{N}_{\mathrm{STU}}=87, \mathrm{~N}_{\mathrm{ACA}}=9, \mathrm{~N}_{\mathrm{MAN}}=2\right)$ \\
\hline & & & & Scope $\left(\mathrm{N}_{\mathrm{STU}}=11, \mathrm{~N}_{\mathrm{ACA}}=16, \mathrm{~N}_{\mathrm{MAN}}=1\right)$ \\
\hline
\end{tabular}

ACA: Academics; MAN: Managers; PAR: Parents; STU: Students

The academics working at institutions with insufficient distance education infrastructure tend to prefer online platforms such as Google Classroom, Edmodo, and Whatsapp. Through these asynchronous platforms, instructors could share various forms of instructional content including class notes, PDF files, presentations, and multimedia materials with students. However, the students reported that their distance classroom experience had been more superficial and theoryheavy than traditional ones. Distance education implementations showed remarkable differences depending on the interest, experience, and knowledge of the academics. For instance, the number of synchronous (live) classroom meetings is quite low. Students noted that asynchronous courses have been far less effective in aiding comprehension and retention than the face-to-face courses that supported active participation. The participants stated that these adversities and uncertainties involved in the process have led them to adopt individual learning activities. However, the thought of missing out valuable information has made them feel insecure about their learning. Considering internet access issues, the students stated that the current situation contradicts the principle of equal opportunity in education. Just like students, sudden changes in the situation have caused academics to feel nervous especially about their health. Students think that their instructors cannot fully apply their methods on digital platforms, and therefore, they may experience dissatisfaction with the quality of work. It can be said that teaching and learning have been constrained in the institutions that failed to meet distance education requirements, and this situation causes problems for all stakeholders.

The students, in general, had issues due to insufficient technological ownership and connectivity problems. Unlike face-to-face education, online distance education requires students 
to have a good internet connection. However, many families do not have enough financial resources to pay for a broadband internet plan. Under the current circumstances, the students expected authorities to improve the accessibility of distance education. In their minds, face-to-face instruction was deemed more effective because it allows for 1-to-1 communication, better fulfillment of students' interests and needs, and active participation. In physical classroom environments, the use of active learning methods, such as question-answer and discussion, increases student motivation. The students stated that, in face-to-face class meetings, they took instructional processes more seriously and felt more confident about their learning. The pandemic had undeniably adverse effects on education. The issues reported by the participants and their solution recommendations are provided in Table 10.

Table 10

Resources, issues, and suggested solutions

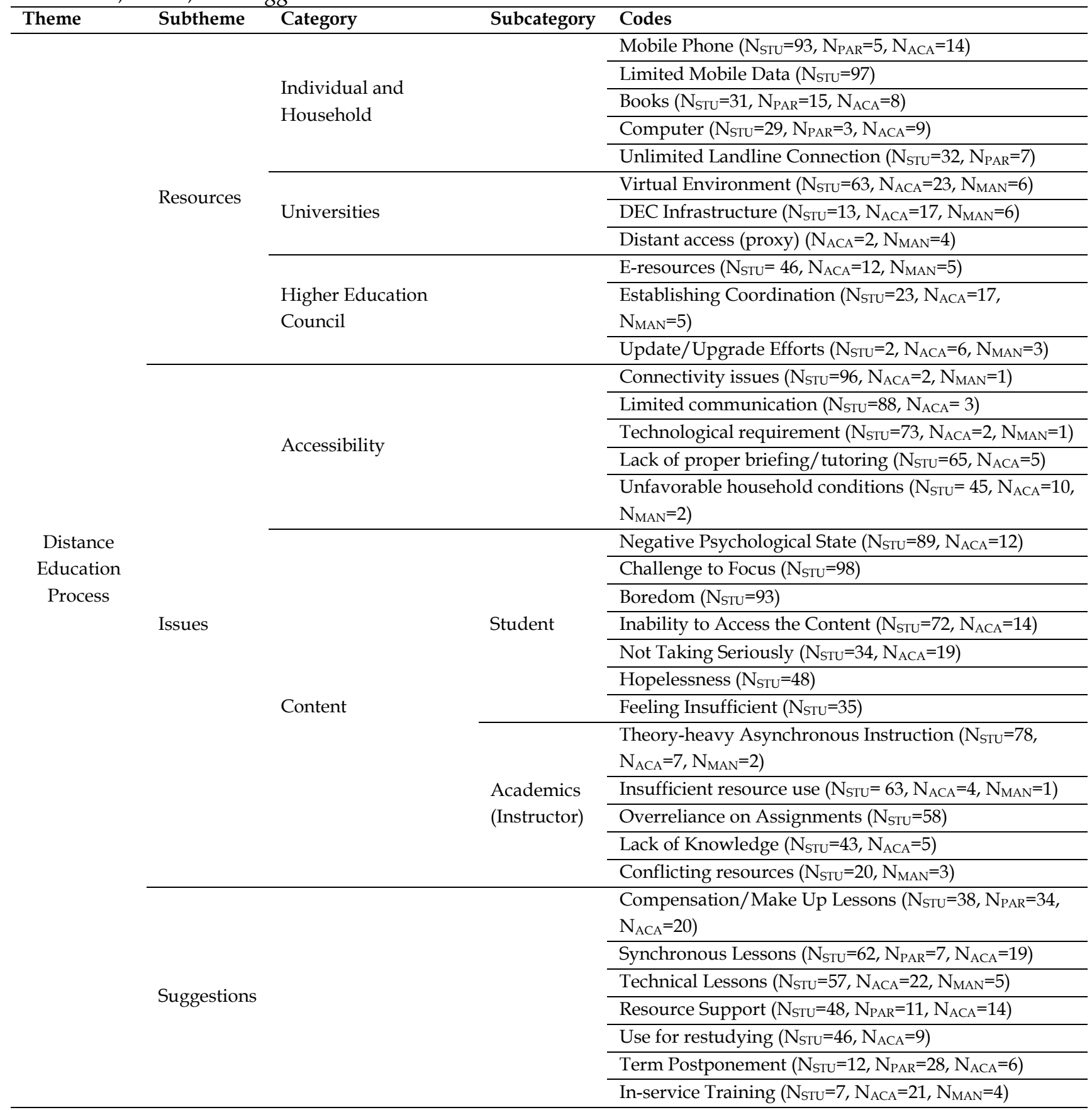


As Table 10 indicates, all participants had a mobile phone; nonetheless, most only had a limited (data-capped) mobile internet plan. The students who resided in the rural areas reported having connectivity problems. Most students used the print books suggested by their instructors as resources, and roughly a third had a personal computer. The ones with unlimited landline connections could use virtual environments more effectively.

Considering the solutions proposed by the students and families, the higher education institutions should immediately start improving their distance education offerings. Also, the participants emphasized that academics should be prepared for diverse learning scenarios through in-service training activities. They also believed that technology courses could help the students attain 21st-century knowledge and skills. The families and students unanimously thought that the 2020 Spring semester should be compensated for. Moreover, the majority suggested offering highquality, interactive synchronous courses over asynchronous ones whenever possible.

In addition to providing quality education, some important steps should be taken to ensure to fairly evaluate students' achievements during and at the end of the process. In this context, the participants' opinions about assessment and evaluation processes are provided in Table 11.

Table 11

Opinions on assessment and evaluation

\begin{tabular}{|c|c|c|c|c|}
\hline Theme & Subtheme & Category & Subcategory & Codes \\
\hline \multirow{31}{*}{$\begin{array}{l}\text { Assessment and } \\
\text { Evaluation }\end{array}$} & \multirow{16}{*}{ Students } & \multirow{10}{*}{ Expectations } & & Fairness $\left(\mathrm{N}_{\mathrm{STU}}=102\right)$ \\
\hline & & & & No victimization $\left(\mathrm{N}_{\mathrm{STU}}=97\right)$ \\
\hline & & & & Empathy $\left(\mathrm{N}_{\mathrm{STU}}=82\right)$ \\
\hline & & & & State of Participation $\left(\mathrm{N}_{\mathrm{STU}}=65\right)$ \\
\hline & & & & Senior-year students $\left(\mathrm{N}_{\mathrm{STU}}=47\right)$ \\
\hline & & & & Reexamining previous terms $\left(\mathrm{N}_{\mathrm{STU}}=31\right)$ \\
\hline & & & & Easy exams $\left(\mathrm{N}_{\mathrm{STU}}=29\right)$ \\
\hline & & & & Being considered successful $\left(\mathrm{N}_{\mathrm{STU}}=25\right)$ \\
\hline & & & & Mutual Platforms $\left(\mathrm{N}_{\mathrm{STU}}=22\right)$ \\
\hline & & & & Suspension / Postponement $\left(\mathrm{N}_{\mathrm{STU}}=11\right)$ \\
\hline & & \multirow{6}{*}{$\begin{array}{l}\text { Evaluation } \\
\text { Approach }\end{array}$} & \multirow{4}{*}{$\begin{array}{l}\text { In-process } \\
\text { (Formative) }\end{array}$} & Online quizzes $\left(\mathrm{N}_{\mathrm{STU}}=109\right)$ \\
\hline & & & & $\begin{array}{l}\text { Online multiple-choice exams } \\
\left(\mathrm{N}_{\mathrm{STU}}=106\right)\end{array}$ \\
\hline & & & & Online Assignments $\left(\mathrm{N}_{\mathrm{STU}}=94\right)$ \\
\hline & & & & Face-to-face exams $\left(\mathrm{N}_{\mathrm{STU}}=83\right)$ \\
\hline & & & \multirow{2}{*}{$\begin{array}{l}\text { At the end } \\
\text { (Summative) }\end{array}$} & $\begin{array}{l}\text { Online projects and research activities } \\
\left(\mathrm{N}_{\mathrm{STU}}=68\right)\end{array}$ \\
\hline & & & & Collective Exam $\left(\mathrm{N}_{\mathrm{STU}}=13\right)$ \\
\hline & \multirow{9}{*}{ Parents } & \multirow{5}{*}{ Expectations } & & Fairness $\left(\mathrm{N}_{\mathrm{PAR}}=38\right)$ \\
\hline & & & & Easy exams $\left(\mathrm{N}_{\mathrm{PAR}}=18\right)$ \\
\hline & & & & Being considered successful $\left(\mathrm{N}_{\mathrm{PAR}}=17\right)$ \\
\hline & & & & Term compenstation $\left(\mathrm{N}_{\mathrm{PAR}}=9\right)$ \\
\hline & & & & No need for examination $\left(\mathrm{N}_{\mathrm{PAR}}=5\right)$ \\
\hline & & \multirow{4}{*}{$\begin{array}{l}\text { Evaluation } \\
\text { Approach }\end{array}$} & \multirow{3}{*}{ In-process } & Assignments $\left(\mathrm{N}_{\mathrm{PAR}}=37\right)$ \\
\hline & & & & Multiple-choice exam $\left(\mathrm{N}_{\mathrm{PAR}}=34\right)$ \\
\hline & & & & Face-to-face exams $\left(\mathrm{N}_{\mathrm{PAR}}=30\right)$ \\
\hline & & & At the end & $\begin{array}{l}\text { Short-Answer Exams/Questions } \\
\left(\mathrm{N}_{\mathrm{PAR}}=26\right)\end{array}$ \\
\hline & \multirow{6}{*}{ Academics } & \multirow{6}{*}{$\begin{array}{l}\text { Evaluation } \\
\text { Approach }\end{array}$} & \multirow{4}{*}{ In-process } & Rubric $\left(\mathrm{N}_{\mathrm{ACA}}=1\right)$ \\
\hline & & & & Project $\left(\mathrm{N}_{\mathrm{ACA}}=1\right)$ \\
\hline & & & & Assignment $\left(\mathrm{N}_{\mathrm{ACA}}=2, \mathrm{~N}_{\mathrm{MAN}}=1\right)$ \\
\hline & & & & Open-Ended Questions $\left(\mathrm{N}_{\mathrm{ACA}}=2\right)$ \\
\hline & & & At the end & Online Exam $\left(\mathrm{N}_{\mathrm{ACA}}=1, \mathrm{~N}_{\mathrm{MAN}}=1\right)$ \\
\hline & & & Grading & Pass-Fail Grading $\left(\mathrm{N}_{\mathrm{ACA}}=1\right)$ \\
\hline
\end{tabular}


As seen in Table 11, the greatest concern and expectation of the participants was the fairness of the assessment and evaluation process. Considering the extraordinary nature of the current circumstances, the participants expected the instructors to be empathetic and tolerant. They also emphasized that no student should be mistreated if grading would be based on examination. As many families have been in a negative psychological and financial state, the participants suggested participation in the virtual activities could be considered during evaluation. Alternatively, some participants suggested postponing/suspending the term or deeming students successful without examination. The participants also raised their concerns about the insufficiency of online examination with multiple-choice questions in preventing cheating and providing fair assessment. They expressed that if the situation requires online assessment they wish to have online research projects and assignments to earn their grades fairly. Having said that, some participants wished to take exams on campus once the distance education phase concluded.

As other stakeholders of educational processes, both DEC managers and academics also expressed some expectations similar to the students and parents. These stakeholder groups suggested that evaluation should take place during or at the end of the process, and grading within the process should be based on assignments. In addition, some believed examination could be done through multiple-choice tests that assign each student questions and answers choices within the question in differing orders. Finally, some others stated that the current situation made the goal of assessing students' achievements in a fair manner unattainable. They suggested assigning pass-fail grades instead of traditional letter grades.

\section{Discussion and Conclusion}

Many countries over the globe have been trying to fight the epidemic without postponing educational activities. While this prolonged fight has made various sections of society nervous, practitioners and policymakers work hard to conclude this period with minimal loss. The current study focused on the quality of distance education implementations in higher education in Turkey and collected data from multiple stakeholder groups. The results indicated that the implementations suffered from infrastructural and psychological issues. In terms of infrastructure, the LMS's offered by the universities were not sufficient to conduct classes. Besides, due to the inequality of opportunities, the students could not participate in the activities as desired. As the extant literature suggests, students and academics could leverage distance education platforms only if they have a fast and stable internet connection (Bao, 2020; Jowsey, Foster, Cooper-Ioelu, \& Jacobs, 2020). From a psychological perspective, it is seen that both the pandemic and the uncertainties involved in the distance education process have led to anxiety and stress. On the other hand, the digital competencies of the academics have appeared as an important asset to assure quality distance education. Before the pandemic, many academics had limited knowledge and experiences about online resources (Jandri, 2020; Toquero, 2020; Zhang et al., 2020). However, they had to use new tools and methods to improve the quality of their distance classrooms (Wang, Cheng et al., 2020). The academics with high-levels of digital literacy were also confident in their capacity to complete the process without significant issues. On the other side, the ones who lacked such literacy faced the fear of insufficiency. In the latter case, providing technical assistance to support and improve the academics' competencies is of importance. Chick et al. (2020) suggested teleconferencing with academics on weekdays and sharing information about distance education during the meetings.

It has seen that quality distance education requires quality content, various presentation formats, and different instructional methods. The academics' skills and experiences defined their attitudes towards distance education. Besides, socio-economical status limited access to digital tools and the internet and, consequently, hindered active participation. On top of the fear of getting infected, exam anxiety negatively affected the feasibility of the process.

The conducted analyses indicated that the pandemic had negative psychological effects on all stakeholders of higher education including students, families, and academics. In all groups, the 
fear of getting infected has raised individuals' levels of anxiety and alter their living conditions. During these extraordinary times, individuals spend more time indoors, and that influenced their social and emotional exchanges negatively (Brooks et al., 2020). The proactive health measures required individuals from all backgrounds to adapt to some financial and emotional changes by compromising their business, education, and social lives. In this process, all members of society faced new living and working conditions with increased responsibilities (Erduran, 2020). Some families even moved from urban regions to rural ones to relive the stress and financial problems. Situations like these have caused negative psychological states such as boredom and depression by triggering emotional hardship. Thus, it appears that the soundness of the process depends on the socio-economical and psychological states of the participants.

Like many other fields of life, the pandemic has had undeniable effects on education. The pandemic has created a huge social experiment about educational systems (Jandri, 2020). Following the very first cases of infection, the authorities in Turkey immediately decided to postpone education at all levels. This decision followed by the idea that instructional activities could continue through distance education. Numerous higher education institutions over the world have taken a similar approach and employed distance education through digital environments (Crawford, et al., 2020). Nonetheless, continuing education has become troublesome for the universities where DECs lacked infrastructural requirements for distance education. To overcome these problems, such higher education institutions turned to alternative tools and obligated academics to utilize them. For synchronous classes, tools that allow multiple simultaneous participants videos such as Zoom, Google Meet, Adobe Connect, and Microsoft Teams were preferred, whereas online educational platforms including Google Classroom and Edmodo were used for asynchronous communication and content sharing (Chick et al., 2020; Jowsey et al., 2020). At this point, it is of importance to compare and contrast the effectiveness of face-to-face instruction and distance education in terms of emotional support, accessibility, feasibility, scope, and resources. Although the academics, students, and families have different responsibilities in this pandemic-driven environment (Bakker \& Wagner, 2020; Zhang et al., 2020), the objectives of higher education institutions hardly changed if at all (Bao, 2020; Crawford, et al., 2020; Toquero, 2020).

As the majority of Turkish universities lacked a sufficient DEC infrastructure, many academics had to choose asynchronous online tools. Wang, Horby et al., (2020) stated that the effectiveness of distance education suffers due to the less-competent academics' inability to provide adequate advisory services to students and their preferences for asynchronous tools. The academics, on the contrary, should support disease prevention measures and the fight against the pandemic, provide advisory services to increase student motivation, and apply different instructional technologies in teaching to improve effectiveness (Wang, Cheng et al., 2020). However, the results indicated that the academics could not use instructional technologies adequately, and they continued to rely mostly on assignments. One of the reasons for this situation is the significantly increased workload of the academics due to simultaneously monitoring students' work and supporting their own children's learning at home (Bakker \& Wagner, 2020; Burgess \& Sievertsen, 2020; Zhang et al., 2020). Ideally, academics are expected to use rich content and provide realistic, practical, interesting, and vivid examples in distance education (Luo et al., 2020). On the other hand, students are expected to internalize the internet and their individual differences and employ information technologies in various ways based on their preferences ( $\mathrm{Zhou}, \mathrm{Wu}, \mathrm{Zhou}, \& \mathrm{Li}, 2020)$. The students were aware that distance education should not be constrained to PDF files, oneway/one-sided presentations, and class notes. Students already challenge to concentrate on their learning due to unfavorable household conditions and psychological issues. Thus, they expect distance education activities to include a variety of instructional technologies to increase and maintain their motivation (Bao, 2020; Wang, Cheng et al., 2020). Effective distance education necessitates more than transferring instructional activities to online environments; therefore, the practitioners should develop appropriate online instructional models and use modern tools to 
address educational needs (Wang, Pan et al., 2020). The practitioners should design learning activities that leverage digital resources that support knowledge and skill development, address needs, and encourage independent learning. In this way, they could recreate curricula, improve instructional practices, and diversify courses.

The students had a mandatory exposure to distance education implementations full of uncertainties, and this situation has caused drastic changes in their habits. For instance, distance learners could experience disrupted sleep schedules, become addicted to technology due to taking courses using only electronics and receive insufficient parental supervision due to unfavorable household conditions (Wang, Zhang et al., 2020). Furthermore, some of the important matters in distance education processes include whether students have favorable household conditions to study, how sufficient their internet connection is, and the effects of increasing responsibility for learning on students (Zhang et al., 2020). In the current study, all student participants had a mobile phone; however, only a third had access to the internet. This is in line with Bakker and Wagner (2020) finding that many students did not have the required technological affordances to participate in online education. Besides, students' lack of self-discipline and independent study skills decrease the efficiency of distance education (Bao, 2020). Thus, it can be said the current situation could have detrimental effects on the academic development of the students who do not have sufficient self-study skills.

Students are known to take teaching and learning processes more seriously in face-to-face classrooms that encourage learning-by-doing and active learning through instructional methods such as question-and-answer and discussion. The students expected practitioners to imitate faceto-face instruction in distance classrooms through various methods that consider students' readiness and provide immediate formative feedback. However, the studies on distance education report that it is hard to maintain instructor-student interactions even if the technological requirements are met; distance education lacks discipline; and prolonged exposure to distance education could have negative effects on students' physical and psychological health (Bao, 2020; Zhang et al., 2020).

Although the universities have utilized instructional technologies to support face-to-face instruction for decades, they rarely preferred e-assessment tools before (Timmis, Broadfoot, Sutherland \& Oldfield, 2016). Consequently, all participants of the current study had doubts about the fairness of assessment activities and expressed great expectations for the assessment systems going to be employed in distance education. Burgess and Sievertsen, (2020) maintained that the novelty of the current situation for both academics and students could lead to more assessment errors than usual. The results of the current study indicated that the stakeholders thought it is hard to conduct assessment activities in the digital medium without a well-established e-examination infrastructure and technical support. In this sense, the results comply with other studies in the literature (e.g., Timmis et al., 2016). Other studies also stressed the importance of developing trustworthy e-assessment systems to conduct assessment and evaluation activities fairly when oncampus examination is not possible (Bakker \& Wagner, 2020; Erduran, 2020). The failure to identify students' learning problems in the process and inaccurate measurements of students' achievement could have undesirable effects on their education.

\subsection{Suggestions}

The pandemic's effects on societies will linger even after this period of mandatory transition from face-to-face instruction to distance education comes to an end (Jandri, 2020). Authorities should take measures to rapidly solve problems in cases that the pandemic continues longer than expected or new pandemics arise (Bakker \& Wagner, 2020; Toquero, 2020; Yue et al., 2020). In the current situation where many countries continue their fights with the pandemic without postponing education, in addition to health and hygiene recommendations (Lunn et al., 2020), there exists a need for studies that examine the pandemic's effects on society (Bakker \& Wagner, 2020). To alleviate the negative psychological effects of the process, experts could provide 
individual or group therapy sessions and online consultation services. In addition to the psychological effects on society, the pandemic also affected teaching and learning activities. In this respect, the dimensions provided in Figure 4 could be considered to improve the quality and efficiency of distance education implementations.

Infrastructure
Computer
The Internet
LMS
Digital Tools

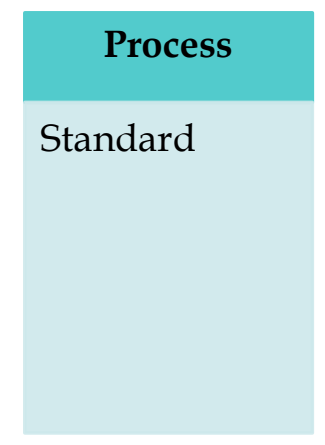

\begin{tabular}{l}
\multicolumn{1}{c}{ Content } \\
Instructional \\
Design \\
Instructional \\
Methods \\
Multimedia
\end{tabular}
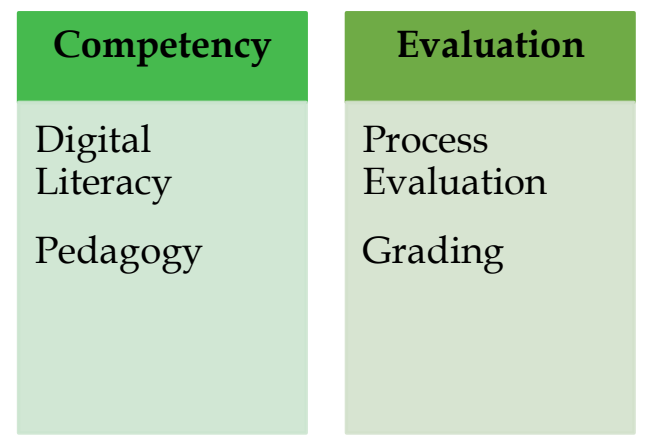

Figure 4. Dimensions of distance education processes

Among the dimension presented in Figure 4, infrastructure is of importance. It is impossible to provide quality distance education without sufficient infrastructure. Online distance education requires internet access and devices with internet capabilities. Therefore, equal opportunities should be provided for both students and academics, and their access to the required technologies should be assured. LMSs and licensed external services should support thousands of simultaneous participants and offer various components/extensions to support instructional activities.

Most [Turkish] universities do not have standards for distance education courses. In this context, it is of importance to establish standards so that process could be more streamlined. HEC should develop a manual that covers effective online learning principles and take steps to minimize the undesirable effects of the process on the students (Toquero, 2020; Wang, Zhang et al., 2020). Moreover, the prospective standards should require DECs to employ experts from the field of Computer Education and Instructional Technology (CEIT) to ensure both technical and instructional aspects of distance education are fulfilled. Distance education is expected to become more prominent in the coming years (Toquero, 2020). In this respect, technological networks could be established between universities to increase collaboration. Moreover, universities should take measures to sustain educational activities in any event without sacrificing quality. It is also of importance to develop well-rounded distance education systems and make them accessible to all universities over the nation.

In distance education, academics are expected to provide quality content. At this point, it should be noted that the content in distance education is similar to that of face-to-face instruction; however, delivering content in the digital medium takes some considerations. Although numerous instructional design models are at practitioners' disposal, ADDIE is regarded as the fundamental model that covers all aspects of instruction, and it could be used when designing distance education courses. The model informs many design-related questions such as how instructional methods will be employed and what multimedia components will be used. Hence, the practitioners could improve the quality of the content by systematically applying the ADDIE model.

The transition to distance education has led to remarkable changes in the students' approaches to learning as well as the academics' teaching methods. In modern distance education, digital tools take the forefront. Online training activities could be conducted to improve the academics' knowledge and skills in using information technologies in education (Wang, Pan et al., 2020). In a similar vein, HEC started the Digital Transformation in Education Movement in 2019 to increase Turkish academics' digital literacy levels. Nonetheless, the training activities conducted within the scope of the movement have been predominantly theoretical and have not provided academics with practical knowledge on how to utilize technology in their teaching. Alternatively, the higher education institutions could provide their teaching personnel with professional development 
activities that focus on application. Zhang et al. (2020) suggested establishing an online instructional feedback system that allows academics to share their experiences and collaborate. On the bright side, the mandatory transition to distance education provided valuable experiences for the authorities on how (not) to reorganize teaching and learning in the face of an emergency and reminded them of the importance of technology integration in education. In this respect, with CEIT professionals' support, the programs of studies offered in various departments could be enriched with new courses that aim to improve students' digital competence.

In addition to being an important component of distance education, assessment and evaluation activities in current implementation could be regarded as the most problematic ones. In cases where students cannot participate in exams on campus, providing trustworthy assessment activities is of importance for accountability (Erduran, 2020). To this end, universities could develop online examination systems. On the other hand, course grades should be not an evaluation of the final results, rather they should be assigned considering all the troubles the stakeholders underwent during the transition. Therefore, open-book exams and online term assignments would be appropriate. Besides, students' performance could be evaluated based on individually-tailored open-ended questions, quizzes, weekly research assignments, and eportfolios. In this way, students could improve their research skills while fulfilling course requirements. Finally, exam safety could be ensured by using parallel tests that assign each student different questions (multiple-choice or open-ended) at the same level of complexity.

\section{References}

Anderson, R. M., Heesterbeek, H., Klinkenberg, D., \& Hollingsworth, T. D. (2020). How will country-based mitigation measures influence the course of the COVID-19 epidemic? The Lancet, 395(10228), 931-934. https://doi.org/10.1016/S0140-6736(20)30567-5

Bakker, A., \& Wagner, D. (2020). Pandemic: lessons for today and tomorrow? Educational Studies in Mathematics, 104(1), 1-4. https:// doi.org/10.1007/s10649-020-09946-3

Bao, W. (2020). COVID -19 and online teaching in higher education: A case study of Peking University. Human Behavior and Emerging Technologies, 2(2), 113-115. https://doi.org/10.1002/hbe2.191

Barr, B., \& Miller, S. (2013). Higher education: The online teaching and learning experience. Retrieved from files.eric.ed.gov/fulltext/ED543912.pdf

Bayham, J., \& Fenichel, E. P. (2020). Impact of school closures for COVID-19 on the US health-care workforce and net mortality: A modelling study. The Lancet Public Health, 5(5), 271-278. https://doi.org/10.1016/S2468-2667(20)30082-7

Brooks, S. K., Webster, R. K., Smith, L. E., Woodland, L., Wessely, S., Greenberg, N., \& Rubin, G. J. (2020). The psychological impact of quarantine and how to reduce it: Rapid review of the evidence. The Lancet, 395(10227), 912-920. https:/ / doi.org/10.1016/S0140-6736(20)30460-8

Burgess, S., \& Sievertsen, H. H. (2020). Schools, skills, and learning: The impact of COVID-19 on education. Vox, 12(8), 245-246. https:/ / voxeu.org/article/impact-covid-19-education

Caladine, R. (2008). Enhancing e-learning with media-rich content and interactions. Hersher, PA: Information Science.

Chick, R. C., Clifton, G. T., Peace, K. M., Propper, B. W., Hale, D. F., Alseidi, A. A., \& Vreeland, T. J. (2020). Using technology to maintain the education of residents during the COVID-19 pandemic. Journal of Surgical Education 77(4), 729-732. https:/ / doi.org/10.1016/j.jsurg.2020.03.018

Corbin, J., \& Strauss, A. (2008). Basics of qualitative research: Techniques and procedures for developing grounded theory (3rd ed.). Thousand Oaks, CA: Sage

Crawford, J., Butler-Henderson, K., Rudolph, J., Malkawi, B., Glowatz, M., Burton, R., Magni, P. A., \& Lam, S. (2020). COVID-19: 20 countries' higher education intra-period digital pedagogy responses. Journal of Applied Learning E Teaching, 3(1), 9-28. https:// doi.org/http://dx.doi.org/10.1680/geot.2008.T.003

Domenico, L. D., Pullano, G., Coletti, P., Hens, N., \& Colizza, V. (2020). Expected impact of school closure and telework to mitigate COVID-19 epidemic in France. 1-15. https://doi.org/10.1101/2020.05.08.20095521

Erduran, S. (2020). Science education in the era of a pandemic: How can history, philosophy and sociology of science contribute to education for understanding and solving the Covid-19 crisis? Science and Education, 29(2), 233-235. https://doi.org/10.1007/s11191-020-00122-w 
Geldsetzer, P. (2020). Knowledge and perceptions of COVID-19 among the general public in the United States and the United Kingdom: A Cross-sectional online survey. Annals of Internal Medicine. https://doi.org/10.7326/M20-0912

Haushofer, J., Jessica, C., Metcalf, E., Björkegren, D., Chandrasekhar, A., De Quidt, J., Grenfell, B., Hussam, R., \& Jayachandran, S. (2020). Combining behavioral economics and infectious disease epidemiology to mitigate the COVID-19 outbreak. Unpublished Manuscript, Princeton University.

Holmberg, B. (2008). The evolution, principles and practices of distance education. Oldenburg: BIS-Verlag der.

Jandri, P. (2020). Safeguard research in the time of COVID-19. Nature Medicine, 26(4), 443. https://doi.org/10.1038/s41591-020-0852-1

Jowsey, T., Foster, G., Cooper-Ioelu, P., \& Jacobs, S. (2020). Blended learning via distance in pre-registration nursing education: A scoping review. Nurse Education in Practice, 44, 102775. https:// doi.org/10.1016/j.nepr.2020.102775

Keegan, D. (1990). Foundations of distance education. London and New York: Routledge.

Kidd, T.T. \& Song, H. (2007). A case study of the adult Learner's Perception of Instructional Quality in webbased online courses. Y. Inoue (Ed), Online education for lifelong learning. Hershey, PA:Information Science Publishing.

Krippendorff, K. (2013). Commentary: A dissenting view on so-called paradoxes of reliability coefficients. Annals of the International Communication Association, 36(1), 481-499.

Lunn, P., Belton, C., Lavin, C., McGowan, F. P. Timmons, S., \& Robertson, D. A. (2020). Using behavioral science to help fight the Coronavirus. Journal of Behavioral Public Administration, 3(1) 1-15. https://doi.org/10.30636/jbpa.31.147

Luo, Y. M., Liu, W., Yue, X. G., \& Rosen, M. A. (2020). Sustainable emergency management based on intelligent information processing. Sustainability (Switzerland), 12(3), 10-13. https:// doi.org/10.3390/su12031081

Mahase, E. (2020). China coronavirus: WHO declares international emergency as death toll exceeds 200. BMJ (Clinical Research Ed.), 368, m408. https:// doi.org/10.1136/bmj.m408

Manderson, L., \& Levine, S. (2020). COVID-19, risk, fear, and fall-out. Medical Anthropology, 39(5), 367-370. https://doi.org/10.1080/01459740.2020.1746301

Martel, M. (2020). COVID-19 effects on U.S. higher education campuses: From emergency response to future student mobility. Report 2, March, 16.

McAleer, M. (2020). Prevention is better than the cure: Risk management of COVID-19. Journal of Risk and Financial Management, 13(3), 46. https://doi.org/10.3390/jrfm13030046

Miles, M. B., Huberman, A. M., \& Saldaña, J. (2014). Qualitative data analysis: A methods sourcebook and the coding manual for qualitative researchers. Thousand Oaks, CA: Sage.

Moore, M., \& Kearsley, G. (2012). Distance education: A systems view of online learning (Third Edition). Belmont, CA: Wadsworth.

Oranburg, S. (2020). Distance education in the time of Coronavirus: Quick and easy strategies for professors. Duquesne University School of Law Research Paper No. 2020-02, available at SSRN Electronic Journal: https:// doi.org/10.2139/ssrn.3553911

Patton, M. Q. (2014). Qualitative research \& evaluation methods: Integrating theory and practice. Thousand Oaks: SAGE Publications, Inc.

Rundle, A. G., Park, Y., Herbstman, J. B., Kinsey, E. W., \& Wang, Y. C. (2020). COVID-19 related school closings and risk of weight gain among children. Obesity, 28(6), 1008-1009. https://doi.org/10.1002/oby.22813

Taylor, J. (2001). Fifth generation distance education (Higher education series, Report No: 40). Canberra, Australia: Department of Education, Training and Youth Affairs.

Timmis, S., Broadfoot, P., Sutherland, R., \& Oldfield, A. (2016). Rethinking assessment in a digital age: Opportunities, challenges and risks. British Educational Research Journal, 42(3), 454-476. https:// doi.org/10.1002/berj.3215

Toquero, C. M. (2020). Challenges and opportunities for higher education amid the COVID-19 pandemic: The Philippine context. Pedagogical Research, 5(4), em0063. https://doi.org/10.29333/pr/7947

UNESCO. (2020). How to plan distance learning solutions during temporary schools closures. https://en.unesco.org/news/covid-19-10-recommendations-plan-distance-learning-solutions

Unwin, D. \& McAleese, R. (1988). The encyclopaedia of educational media communications and technology. New York: Greenwood Press. 
Wang, Chen, Horby, P. W., Hayden, F. G., \& Gao, G. F. (2020). A novel coronavirus outbreak of global health concern. The Lancet, 395(10223), 470-473. https:/ / doi.org/10.1016/S0140-6736(20)30185-9

Wang, Chuanyi, Cheng, Z., Yue, X.-G., \& McAleer, M. (2020). Risk management of COVID-19 by Universities in China. Journal of Risk and Financial Management, 13(2), 36. https:/ / doi.org/10.3390/jrfm13020036

Wang, Cuiyan, Pan, R., Wan, X., Tan, Y., Xu, L., Ho, C. S., \& Ho, R. C. (2020). Immediate psychological responses and associated factors during the initial stage of the 2019 coronavirus disease (COVID-19) epidemic among the general population in China. International Journal of Environmental Research and Public Health, 17(5). https:// doi.org/10.3390/ijerph17051729

Wang, G., Zhang, Y., Zhao, J., Zhang, J., \& Jiang, F. (2020). Mitigate the effects of home confinement on children during the COVID-19 outbreak. The Lancet, 395(10228), 945-947. https:// doi.org/10.1016/S01406736(20)30547-X

Yue, X.-G., Shao, X.-F., Li, R., Crabbe, M., Mi, L., Hu, S., Baker, J., \& Liang, G. (2020). Risk management analysis for novel Coronavirus in Wuhan, China. Journal of Risk and Financial Management, 13(2), 22-27. https://doi.org/10.3390/jrfm13020022

Zhang, W., Wang, Y., Yang, L., \& Wang, C. (2020). Suspending classes without stopping learning: China's education emergency management policy in the COVID-19 outbreak. Journal of Risk and Financial Management, 13(3), 55-61. https:// doi.org/10.3390/jrfm13030055

Zhao, J., Lyngs, U., \& Shadbolt, N. (2018). What privacy concerns do parents have about children's mobile apps, and how can they stay SHARP?-KOALA Project Report 1. ArXiv Computers and Society. Retrieved from https:/ /arxiv.org/pdf/1809.10841.pdf

Zhou, L., Wu, S., Zhou, M., \& Li, F. (2020). 'School's out, but class' on', the largest online education in the world today: Taking China's practical exploration during the COVID-19 epidemic prevention and control as an example. Best Evid Chin Edu, 4(2), 501-519. http://dx.doi.org/10.2139/ssrn.3555520 